\title{
CONTINUATION VERSUS DISCONTINUATION OF OXYTOCIN INFUSION THROUGHOUT THE ACTIVE PHASE OF LABOR AND ITS EFFECT ON THE COURSE OF INDUCED LABOR
}

\author{
By \\ Mohamed Morad Abd El-Hakem, Farid Ibrahim Hassan and Wael \\ Soliman Taha
}

Department of Obstetrics and Gynecology, Al-Azhar Faculty of Medicine, Cairo, Egypt

E-mail: $\underline{\operatorname{drm} 7 \text { medmorad@gmail.com }}$

\begin{abstract}
Background: Oxytocin is an effective commonly used drug for induction of labor, However it is associated with several maternal and neonatal adverse effect. So, controlled dosage is recommended.

Objective: To determine the effect of continuation or discontinuation of the infusion of oxytocin on the duration of the active phase of labor and maternal and neonatal complications.

Patients and Methods: This was a randomized controlled trial study conducted in the Obstetrics and Gynecology Department of Dikirnis General Hospital from (August 2018 to September 2019). The women participated in this study was divided in 2 groups, each group consists of 100 women [40 of them were nulliparous and 60 were multiparous]: Group (A) received continuous oxytocin infusions throughout labor until the end of labor. Group (B) received oxytocin infusion which was discontinued once the active phase of labor was established (cervix $\geq 6 \mathrm{~cm}$, uterine contraction at a rate of 3-5 per 10 minutes).

Results: The active phase of labor was longer by 53 minutes in the discontinued group (primigravida) versus the continued group (primigravida) and was longer by 75 minutes in the discontinued group B (multigravida) versus the continued group A (multigravida). The incidence of intrapartum fetal distress and uterine hyperstimulation were non-significantly greater in the continued than the discontinued group. The mode of delivery, incidence of cesarean deliveries, postpartum hemorrhage, cervical tear and NICU admission were higher in the continued group versus the discontinued group.
\end{abstract}

Conclusion: The duration of active phase of labor prolonged after discontinuing oxytocin infusion. The new protocol may improve labor outcomes and significantly decrease the rate of uterine hyperstimulation, intrapartum fetal distress and decrease cesarean delivery.

Keywords: Active phase of labor, cesarean delivery, discontinuation of oxytocin, fetal heart rate abnormalities, hyperstimulation.

\section{INTRODUCTION}

From the time when oxytocin was first synthesized in 1953, it has become one of the most commonly used medications in obstetrics to induce and augment labor. Oxytocin is used in more than $50 \%$ of deliveries in several delivery units (Boie et al., 2019). Although various oxytocin usages for the induction of labor have been defined relatively, few studies have focused on the duration of oxytocin administration in labor (Bugg et al., 2013). The use of oxytocin during labor may cause a number of maternal adverse effects including hypotension, 
tachycardia, arrhythmias, nausea, vomiting, headache and flushing. High doses of oxytocin may also cause water retention, hyponatremia, myocardial ischemia, seizures and coma (Liu et al., 2018). Long duration of labor induction or augmentation due to use of oxytocin, decreases the efficacy of labor and increases complication rates (Zhang et al., 2011). These problems are usually common due to the inappropriate administration of oxytocin and lack of timely detecting the treatment of excessive uterine activity (Gabbe et al., 2016). To reduce the rate of maternal and fetal adverse events due to inappropriate or unnecessary oxytocin administration, a standard and specific protocol is needed (Grotegut et al., 2018).

The aim of this prospective study was to examine the effects of discontinuing oxytocin infusion in labor progress on maternal and fetal outcomes versus its usage once the active phase of labor is started during its induction.

\section{PATIENTS AND METHODS}

This was a randomized controlled trial study conducted in the Obstetrics and Gynecology Department of Dikirnis General Hospital from (August 2018 to September 2019). This study included two hundred pregnant women randomly divided in two equal groups. They were subjected to labor induction by continuous oxytocin infusion in Group $\mathrm{A}$, and discontinuous oxytocin infusion in Group B.

\section{Ethical Consideration:}

Pregnant women had agreed to be included in the study and gave informed consents.

\section{Inclusion Criteria:}

1. All cases had indication for induction of labor.

2. Pregnant at 37 completed weeks or more.

3. Cephalic presentation.

4. Adequate pelvis.

5. Favorable cervix for labor induction (using Bishop Score of 8 or more).

\section{Exclusion Criteria:}

- Cephalopelvic disproportion.

- Had contraindication to vaginal delivery (e.g. pervious uterine surgery).

- Had persistent non-reassuring fetal well-being tests (NST, Biophysical profile).

- Placental abnormalities (placenta previa, placenta accrete).

- Estimated fetal weight > $4.5 \mathrm{~kg}$ by ultrasound.

- Patient in spontaneous labor.

- Use of other inducing drugs like prostaglandins.

- Patients with unfavorable cervix.

All pregnant women involved in the study were subjected to detailed history on admission, detailed physical examination and investigations: $\mathrm{ABO}, \mathrm{CBC}, \mathrm{RH}$, random blood glucose, albumin in urine and pelvi abdominal ultrasound.

Induction of labor started in all pregnant women by oxytocin IV drip infusion at a rate of $1 \mathrm{mIU} / \mathrm{minute}$ (5 IU of oxytocin was diluted in $500 \mathrm{ml}$ of $0.9 \%$ $\mathrm{NaCl}$ ). The dose increased every 20 minutes by $1 \mathrm{mIU} /$ minute until regular contractions at a rate of $3-5$ per 10 
minutes reached. The maximal allowed dose of oxytocin was $20 \mathrm{mIU} /$ minute. Amniotomy was performed in those with intact membranes at the beginning of the active phase.

\section{All pregnant women were monitored throughout the labor stages by:}

1. Blood pressure, pulse and temperature were measured every hour.

2. Auscultation of FHR was done by sonicaid and recorded in every stage.

Intervention stopped when there was suspicious or abnormal FHR or occurrence of uterine hypertonus.

Vaginal examination was done every 1-2 hours, and labor progress was assessed by partogram.

Primary outcome: Duration from the start of active phase of labor to delivery in the two groups.

\section{Secondary outcome: Occurrence of complications:}

- Abnormalities in fetal heart rate during labor.

- Need for assisted delivery.

- Uterine hypertonus.

- Postpartum hemorrhage (Atonic or Traumatic).
- Cervical tear.

- Arrested progress of labor.

- Neonatal low APGAR score at 5 min.

- Need for NICU admission.

\section{Statistical Analysis:}

Data were collected, revised, coded and entered to the Statistical Package for the Social Sciences (IBM SPSS) version 23. The distribution of quantitative data was tested by Kolmogorov-Smirnov test of normality. So, the quantitative data were presented as mean, standard deviations and ranges when parametric. Also, qualitative variables were presented as number and percentages.

The comparison between groups regarding qualitative data was done by using Chi-square test or Fisher exact test when the expected count in any cell found less than 5. The comparison between two independent groups with quantitative data and parametric distribution was done by using Independent t-test. The confidence interval was set to $95 \%$ and the margin of error accepted was set to $5 \%$. So, the pvalue was considered significant when $\mathrm{P} \leq$ 0.05 .

\section{RESULTS}

There were no significant statistical differences between the two groups in the demographic characteristics. The indication for induction cases in the two groups were premature rupture of membranes (PROM), postdate and oligohydramnios (Table 1). 
Table (1): Comparison of the maternal characterises and indication for induction cases between the two groups.

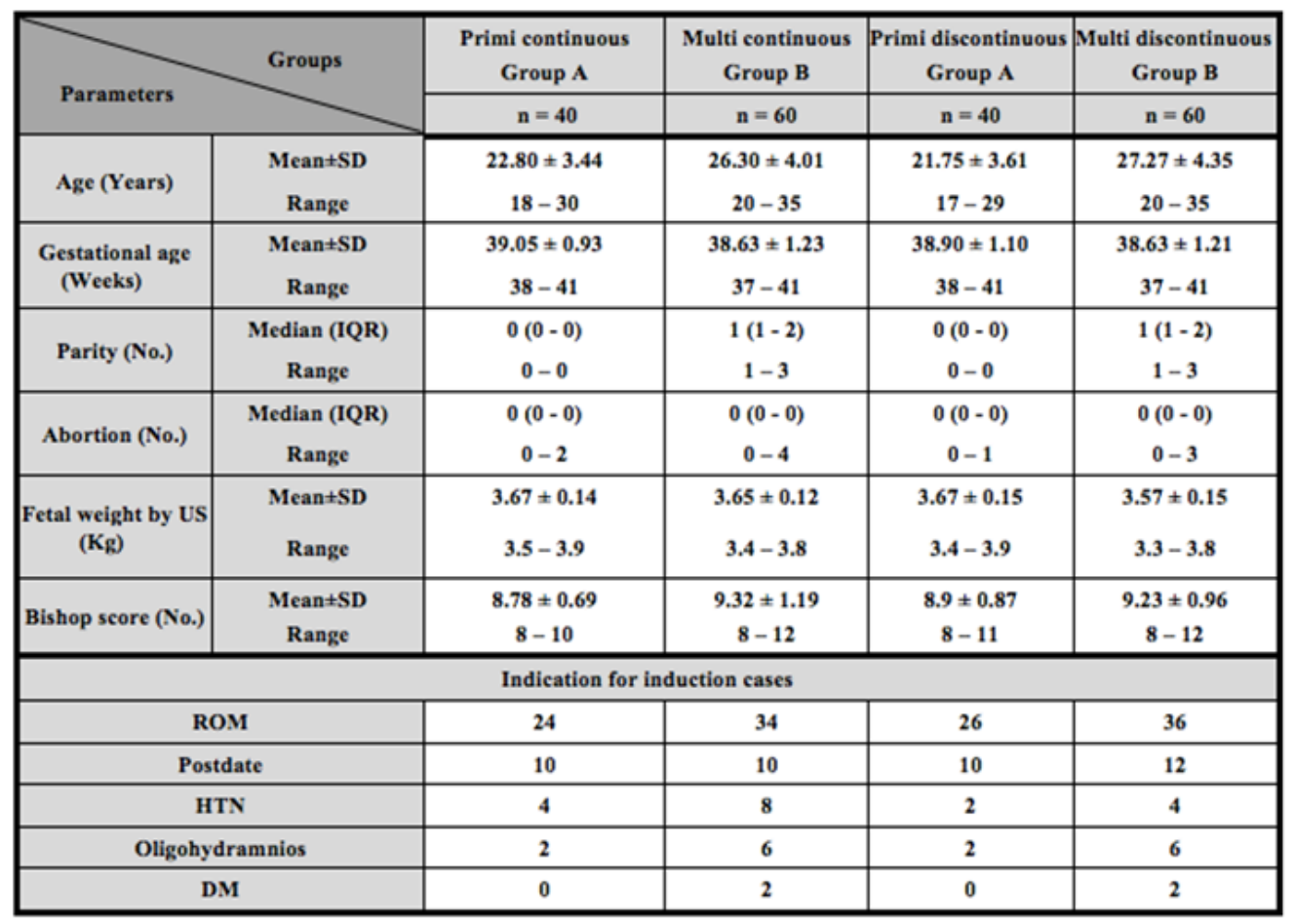

There was no significant difference between the two groups in the failure of induction during the latent phase. The duration of the active phase of labor was significantly shorter among continuous groups than among discontinuous groups and significantly shorter among multi groups than among primi groups. The duration of the second stage and the third stage of labor were significantly shorter among continuous groups than among discontinuous groups and significantly shorter among multi groups than among primi groups (Table 2).

Table (2): Comparison of failure of induction, latent phase, active phase, second stage and third stage duration between the two groups.

\begin{tabular}{|c|c|c|c|c|c|c|}
\hline \multirow{2}{*}{ Parameters } & Groups & $\begin{array}{l}\text { Primi continuous } \\
\text { Group A }\end{array}$ & $\begin{array}{c}\text { Multi continuous } \\
\text { Group B }\end{array}$ & $\begin{array}{c}\text { Primi discontinuous } \\
\text { Group A }\end{array}$ & $\begin{array}{c}\text { Multi discontinuous } \\
\text { Group B }\end{array}$ & \multirow[t]{2}{*}{ P-Value } \\
\hline & & $n=40$ & $n=60$ & $n=40$ & $\mathrm{n}=60$ & \\
\hline \multicolumn{2}{|c|}{ Failure of induction } & 2 & 1 & 3 & 2 & $>0.05$ \\
\hline $\begin{array}{l}\text { Latent phase } \\
\text { duration (hr.) }\end{array}$ & $\begin{array}{c}\text { Mean }+S D \\
\text { Range }\end{array}$ & $\begin{array}{c}4.02+2.05 \\
3.7-4.4\end{array}$ & $\begin{array}{c}3.49 \pm 0.71 \\
3.1-3.9\end{array}$ & $\begin{array}{c}4.27 \pm 0.30 \\
3.8-4.9\end{array}$ & $\begin{array}{c}3.49 \pm 0.25 \\
2.4-3.9\end{array}$ & $>0.05$ \\
\hline $\begin{array}{l}\text { Active phase } \\
\text { duration (hr.) }\end{array}$ & $\begin{array}{c}\text { MeanæSD } \\
\text { Range }\end{array}$ & $\begin{array}{c}3.36 \pm 0.57 \\
2.4-4.2\end{array}$ & $\begin{array}{c}2.42 \pm 0.84 \\
1.2-3.9\end{array}$ & $\begin{array}{c}4.25 \pm 0.87 \\
2.6-5.5\end{array}$ & $\begin{array}{c}3.67 \pm 0.76 \\
2.5-5\end{array}$ & $>0.001$ \\
\hline $\begin{array}{r}\text { Second stage } \\
\text { duration (min.) }\end{array}$ & $\begin{array}{c}\text { Mean } \pm S D \\
\text { Range }\end{array}$ & $\begin{array}{c}24.93 \pm 2.91 \\
20-30\end{array}$ & $\begin{array}{c}18.98+3.45 \\
10=25\end{array}$ & $\begin{array}{c}32.46 \pm 3.16 \\
26-37\end{array}$ & $\begin{array}{c}24.09 \pm 5.46 \\
15-33 \\
\end{array}$ & $<0.001$ \\
\hline $\begin{array}{c}\text { Third stage } \\
\text { duration (min.) }\end{array}$ & $\begin{array}{c}\text { MeantSD } \\
\text { Range }\end{array}$ & $\begin{array}{c}5.1+1.92 \\
2-10\end{array}$ & $\begin{array}{c}4.92+1.32 \\
2-7\end{array}$ & $\begin{array}{c}8.11+1.94 \\
5-12\end{array}$ & $\begin{array}{c}7.41+2.4 \\
3-12\end{array}$ & $<0.001$ \\
\hline
\end{tabular}


The rate of uterine hyperstimulation and intrapartum fetal distress were nonsignificantly more frequent among continuous groups than among discontinuous groups. In the continued group A, oxytocin infusion was stopped, the care of 31 women (in discontinued group B and continued group A) were asked to change position to left lateral position and administered with IV fluid and Oxygen mask. The rates of uterine hyperstimulation and intrapartum fetal distress were the main indications in the two groups. The mean cervical dilation was $6 \mathrm{~cm}$ in 16 of these women $(16 / 31$, $51 \%$ ) had normal vaginal delivery when (symptoms was relieved) and (15/31, $48 \%$ ) had caesarean delivery when (symptoms were not relieved). There were no significant differences between the rates of CS delivery when oxytocin was stopped in the (continued Group A) compared to the discontinued Group B (Table 3).

Table (3): Comparing the rate of uterine hyperstimulation and intrapartum fetal distress between the two groups.

\begin{tabular}{|c|c|c|c|c|c|}
\hline \multirow{2}{*}{ Parameters } & $\begin{array}{l}\text { Primi continuous } \\
\text { Group A }\end{array}$ & $\begin{array}{l}\text { Multi continuous } \\
\text { Group B }\end{array}$ & $\begin{array}{c}\text { Primi discontinuous } \\
\text { Group A }\end{array}$ & $\begin{array}{c}\text { Multi discontinuous } \\
\text { Group B }\end{array}$ & \multirow[t]{2}{*}{ P-Value } \\
\hline & $n=40$ & $\mathrm{n}=60$ & $n=40$ & $\mathrm{n}=60$ & \\
\hline \multicolumn{6}{|c|}{$\begin{array}{l}\text { *Oxytocin infusion stopped in (Group A). All Pregnant women were asked to change position to left lateral position and administered with IV fluid } \\
\text { and Oxygen mask. }\end{array}$} \\
\hline $\begin{array}{l}\text { Uterine hyperstimulation relieved and fetal } \\
\text { heart rate patterns retumed to normal }\end{array}$ & 3 & 3 & 1 & 1 & \multirow{4}{*}{$>0.05$} \\
\hline $\begin{array}{l}\text { Uterine hyperstimultaion "not relieved } \\
\text { with persistent abnormal fetal heart rate } \\
\text { patterns and had immediate CS delivery }\end{array}$ & 1 & 3 & 0 & 1 & \\
\hline $\begin{array}{l}\text { Intrapartum fetal distress relieved and fetal } \\
\text { heart rate patterns retumed to normal }\end{array}$ & 3 & 4 & 0 & 1 & \\
\hline $\begin{array}{l}\text { Intrapartum fetal distress "not relieved } \\
\text { with persistent abnomal fetal heart rate } \\
\text { patterns and had immediate CS delivery }\end{array}$ & 3 & 4 & 2 & 1 & \\
\hline
\end{tabular}

There were significant differences between the two groups regarding the mode of delivery. The number of CS was more frequent in continuous group A than discontinuous group B. Also, In contrast, the rate of ventose was dominant in the case of discontinuous group and more in the case of primi groups than multi groups. The indications of cesarean deliveries, cervical tear and PPH were greater in the continued group A than the discontinued group B; however, these differences were not significant in both groups. Regarding the comparison between the two groups on the neonatal outcomes: (APGAR score $<7.0$ at $5 \mathrm{~min}$ ) and (NICU admission) there were no significant differences between the two groups, but more frequent in the continued group A than discontinued group B (Table 4). 
Table (4): Comparison of mode of delivery, indications of CS, cervical tear, PPH, APGAR score and NICU admission between the two groups.

\begin{tabular}{|c|c|c|c|c|c|}
\hline \multirow{2}{*}{ Parameters } & $\begin{array}{c}\text { Primi continuous } \\
\text { Group A } \\
\end{array}$ & $\begin{array}{c}\text { Multi continuous } \\
\text { Group B } \\
\end{array}$ & $\begin{array}{c}\text { Primi discontinuous } \\
\text { Group A }\end{array}$ & $\begin{array}{c}\text { Multi discontinuous } \\
\text { Group B } \\
\end{array}$ & \multirow[t]{2}{*}{ P-Value } \\
\hline & $n=40$ & $\mathrm{n}=60$ & $\mathrm{n}=40$ & $\mathrm{n}=60$ & \\
\hline \multicolumn{6}{|l|}{ Mode of delivery: } \\
\hline SVD & 27 & 48 & 27 & 50 & \multirow{3}{*}{$>0.05$} \\
\hline Cs & 10 & 11 & 6 & 6 & \\
\hline Ventose & 1 & $\mathbf{0}$ & 4 & 2 & \\
\hline \multicolumn{6}{|l|}{ Indications of CS: } \\
\hline Intrapartum fetal distress & 3 & 4 & 2 & 1 & \multirow{7}{*}{$>0.05$} \\
\hline Obstruction & 1 & 0 & 1 & 1 & \\
\hline Non progress & 2 & 1 & 0 & 1 & \\
\hline Abruptio placentae & 1 & 1 & 0 & $\mathbf{0}$ & \\
\hline Rupture uterus & 0 & 1 & 0 & $\mathbf{0}$ & \\
\hline Hyperstimulation & 1 & 3 & 0 & 1 & \\
\hline Failure of Induction & 2 & 1 & 3 & 2 & \\
\hline Cervical tear & 2 & 2 & 1 & 1 & \multirow{4}{*}{$>0.05$} \\
\hline Postpartum Hemorrhage PPH $>500 \mathrm{ml}$. & 2 & 4 & 1 & 2 & \\
\hline APGAR score $<7$ at $5 \mathrm{~min}$. & 2 & 4 & 1 & 1 & \\
\hline NICU Admission & 4 & 8 & 2 & 4 & \\
\hline
\end{tabular}

\section{DISCUSSION}

In the current study, there were no significant statistical differences between the two groups, as regards the demographic characteristics. The indication for induction cases were premature rupture of membranes (PROM), postdate and oligohydramnios. However, there were no significant differences between the two groups. In addition, there were no significant differences between the two groups in the failure of induction during the latent phase. These results agreed with Bor et al. (2016) and Drummond, (2018) who reported no significant difference on the maternal characteristics or indications for induction.

In our study, the duration of the active phase of labor was significantly longer in discontinuous group $\mathrm{B}$ than continuous group A by 53 minutes in the case of primigravida and 75 minutes in the case of multigravida. The discontinuation of oxytocin during the active phase may improve labor outcomes. This study agreed with Bor et al. (2016) who reported that the duration of the active phase of labor prolonged by 41 minutes when oxytocin infusion was discontinued. Also, Hernandez-Martínez et al. (2019) found that the active phase was around 2 hours longer when oxytocin was discontinued.

A comparison between our study and previous studies showed that the active phase is prolonged when oxytocin was discontinued during the active phase of labor (Diven et al., 2012 and Ozturk et al., 2015). Most women may tolerate or even prefer a longer phase of labor if contractions are less painful (NICE, 
2014). Bor et al. (2016) suggested that 6 $\mathrm{cm}$ cervical dilation could be more effective for the start of the active phase of labor. On the other hand, Chopra et al. (2015) found only 30 minutes prolongation and reported that oxytocin discontinuation in the active phase of labor did not prolong the active phase. The total duration of labor and total oxytocin dose were significantly less in the oxytocin discontinuation group.

Our study showed that the rate of uterine hyperstimulation and intrapartrum fetal distress was non-significantly more frequent among continuous group A than among discontinuous group B. Also, oxytocin administration duration was significantly shorter in the discontinuous group than the continuous group. This agreed with the findings in Drummond, (2018) who reported more uterine hyperstimulation when oxytocin was continued until delivery. The uterine hyperstimulation was related to the dosage of oxytocin regimen. In this study, we found that the number of cesarean sections were higher in the group in which oxytocin was continued until delivery.

Also, other supporting studies have found that discontinuing oxytocin after the start of the active phase of labor may reduce uterine tachysystole with fetal heart rate (FHR) changes and cesarean delivery. The oxytocin discontinuation had little or no effect on cesarean delivery (Boie et al., 2019).

In addition, this study agreed with Bor et al. (2016) and Saccone et al. (2017) who reported that when oxytocin was discontinued at the beginning of the active phase. They found significantly lower rate of uterine hyperstimulation and a non- significantly lower rate of caesarean sections. The effect of oxytocin discontinuation in the active phase of labor showed significantly decreased rates of cesarean sections, uterine hyperstimulation and non-reassuring FHR patterns when oxytocin was discontinued during the active phase of labor.

There were significant differences between the two groups regarding the mode of delivery. It was noticed that the number of CS was more frequent in continuous group A than discontinuous group B (54\% vs. 26\%) that represented the effect of oxytocin continuation on the mode of delivery. In fact, the rate of ventose was higher in the case of discontinuous group B. This demonstrated the effect of discontinuation of oxytocin on using assisted vaginal. This study agreed with Ozturk et al. (2015) who reported significant differences in the continued group of oxytocin infusion on the mode of delivery. The effect of different factors needs further analysis with higher sample.

On the other hand, the results of Kenyon et al. (2013) disagreed with our findings. They reported that oxytocin was not associated with increased rates of caesarean delivery in women who presented with slow progress of labor. They also suggested that higher doses of oxytocin might be associated with lower rates of cesarean delivery according to the results of their meta-analysis, which was based on four randomized trials.

We found PPH and cervical tear were greater in the continued group than the discontinued group. However, these differences were not significant. This study agreed with Pantoja et al. (2016) 
who found no significant difference of $\mathrm{PPH}$ in the continued group than discontinued group. They indicated that the risk of $\mathrm{PPH}$ associated with labor induction might be limited to unfavorable obstetrical emergencies.

Also, in our study there were no significant differences between the two groups in the APGAR score $<7.0$ at $5 \mathrm{~min}$ and NICU admission but more frequent in the continuous group A than discontinuous group B. This result agreed with Hernandez-Martínez et al. (2019) who showed no significant differences on the neonatal outcomes in the group with continued oxytocin infusion than the discontinued group.

Another study reviewed that a low dose oxytocin regimen, which includes a lower initial dose of oxytocin, a lower incremental dose of oxytocin and a longer period between the oxytocin doses incremental is clinically acceptable. Careful assessment should always be maintained in both maternal and neonatal well-being (Selin et al., 2019).

\section{CONCLUSION}

There is no need to continue oxytocin infusion after the start of active phase of labor. This study had showed significant decrease in the incidence of uterine hyperstimulation, intrapartum fetal distress and may reduce cesarean delivery rate due to oxytocin complications. Also, it showed decrease in maternal and neonatal outcomes. In fact, the duration of labor prolonged when oxytocin was discontinued during the active phase of labor. That finding was comparable to previous studies and there was no effect on the progress of labor.

\section{REFERENCES}

1. Boie S, Glavind J, Uldbjerg N, Bakker JJH, van der Post JAM and Steer PJ (2019): CONDISOX- continued versus discontinued oxytocin stimulation of induced labour in a double-blind randomized controlled trial. BMC Pregnancy and Childbirth, 19(1):320-27.

2. Bor P, Ledertoug S, Boie S, Knoblauch NO and Stornes I (2016): Continuation versus discontinuation of oxytocin infusion during the active phase of labour: a randomized controlled trial. BJOG, 123(1):129-35.

3. Bugg GJ, Siddiqui $F$ and Thornton JG (2013): Oxytocin versus no treatment or delayed treatment for slow progress in the first stage of spontaneous labour. Cochrane Database Syst Rev., CD007123. Review. PMID: 23794255.

4. Chopra S, SenGupta SK, Jain $V$ and Kumar P (2015): Stopping Oxytocin in Active Labor Rather Than Continuing it until Delivery: A Viable Option for the Induction of Labor. Oman Med J., 30(5):320-325.

5. Diven LC, Rochon ML, Gogle J, Eid S, Smulian JC and Quinones JN (2012): Oxytocin discontinuation during active labor in women who undergo labor induction. Am J Obstet Gynecol., 207:471-8.

6. Drummond S, (2018): Oxytocin Use in Labor. The Journal of Perinatal \& Neonatal Nursing, 32(1):34-42.

7. Gabbe SG, Niebyl JR, Galan HL, Landon MB and Driscoll, DA (2016): Obstetrics: normal and problem pregnancies e-book. Elsevier Health Sciences, 13(7): 271-288.

8. Grotegut CA, Lewis LL, Manuck TA, Allen TK, James AH, Seco A and DeneuxTharaux C (2018): The oxytocin product correlates with total oxytocin received during labor: a research methods study. American Journal of Perinatology, 35(1):78-83.

9. Hernández-Martínez A, Arias-Arias A, Morandeira-Rivas A, Pascual-Pedreño A I, Ortiz-Molina E J and Rodriguez-Almagro, J (2019): Oxytocin discontinuation after the 
active phase of induced labor: A systematic review. Women and Birth, 32(2): 112-118.

10. Kenyon S, Tokumasu H, Dowswell T, Pledge $D$ and Mori $R$ (2013): High-dose versus low dose oxytocin for augmentation of delayed labour. Cochrane Database of Syst Rev., 7:CD0072016.

11. Liu J, Yi Y and Weiwei X (2018): Effects of increased frequency, high dose, and pulsatile oxytocin regimens on abnormal labor delivery. Medical science monitor: international medical journal of experimental and clinical research., 24:2063-2071.

12. National Institute of Clinical Excellence, (NICE) (2014): CG190-Clinical guideline Intrapartum care: care of healthy women and their babies during childbirth. London, UK: NICE guidelines, 1(16):10-15.

13. Öztürk FH,Yılmaz SS,Yalvac S and Kandemir Ö (2015): Effect of oxytocin discontinuation during the active phase of labor. J Matern Fetal Neonatal Med., 28:1968 .
14. Pantoja T, Abalos E, Chapman E, Vera C and Serrano VP (2016): Oxytocin for preventing postpartum haemorrhage (PPH) in non-facility birth settings. Cochrane Database of Systematic Reviews., 10: CD011491.

15. Saccone G, Ciardulli A, Baxter JK, Quiñones JN, Diven LC and Berghella V (2017): Discontinuing oxytocin infusion in the active phase of labor: a systematic review and meta-analysis. Obstetrics \& Gynecology., 130(5): 1090-1096.

16. Selin L, Wennerholm UB, Jonsson M, Dencker A, Wallin G, Wiberg-Itzel E, Almström E, Petzold $M$ and Berg $M$ (2019): High-dose versus low-dose of oxytocin for labour augmentation: a randomized controlled trial. Women and Birth, 32(4):356-63.

17. Zhang J, Branch DW, Ramirez MM, Laughon SK, Reddy $U$ and Hoffman $M$ (2011): Oxytocin regimen for labor augmentation, labor progression, perinatal outcomes. Obstet Gynecol., 2118(2 Pt 1):249-56. 
مقارنة بين استمرار التتقيط الوريدى لعقار الأوكسيتوسين

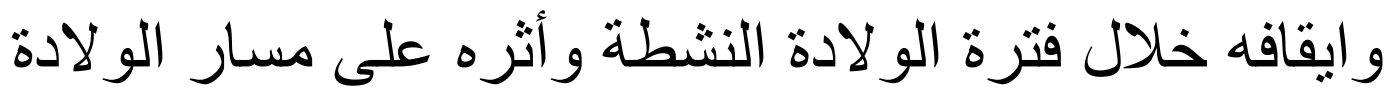

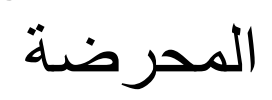

محمد مراد عبد الحكيم, فريد ابراهيم حسن, وائل سليمان طه الهانه

قسم النساء و التوليل, كليه الطب، جامعة الأزهر

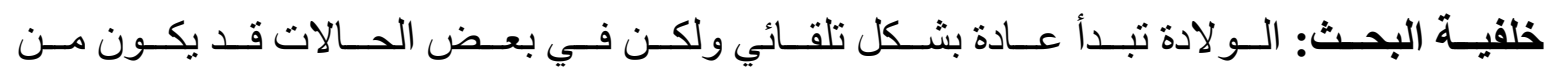

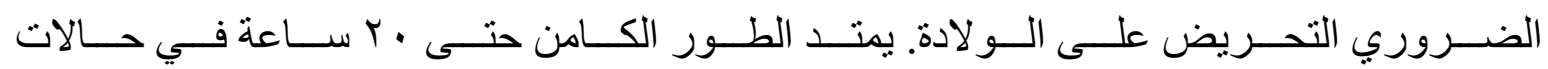

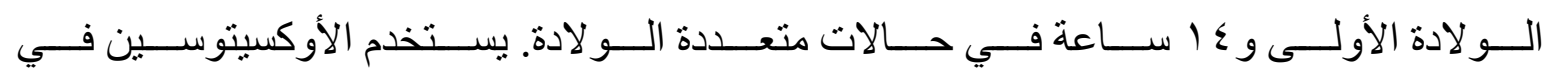

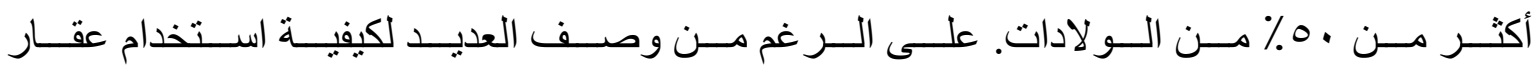

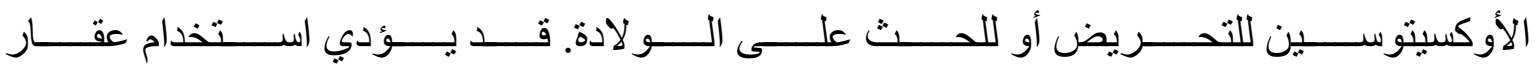

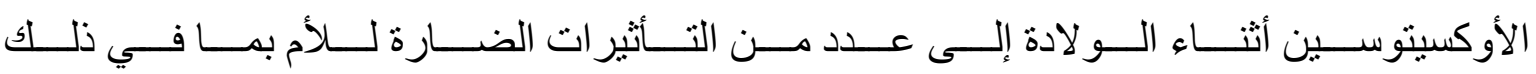

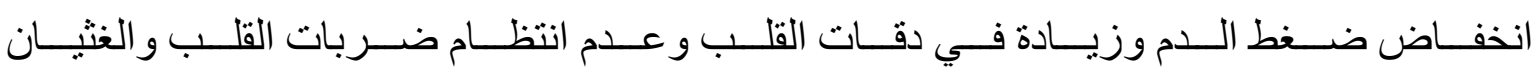

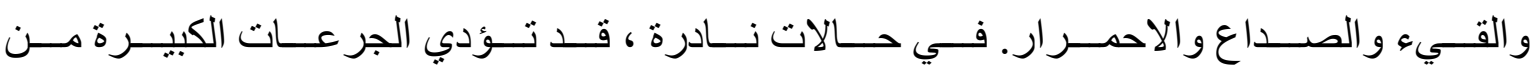

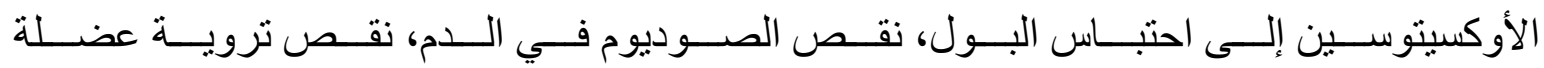

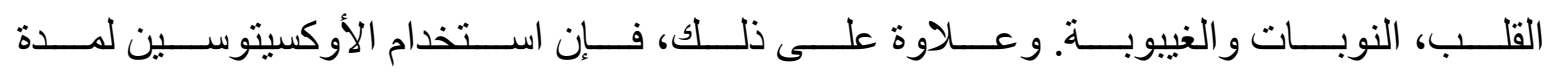

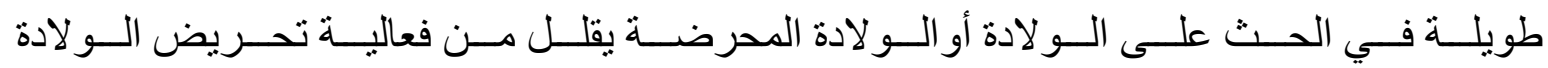

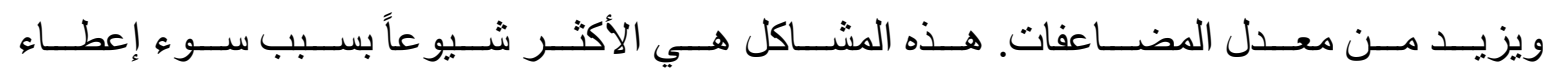

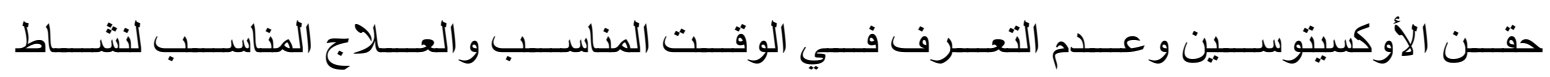

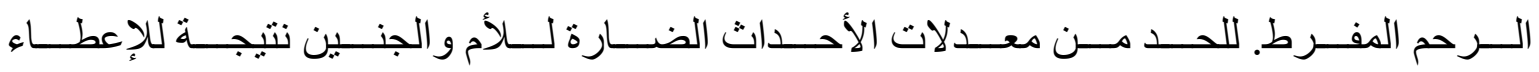

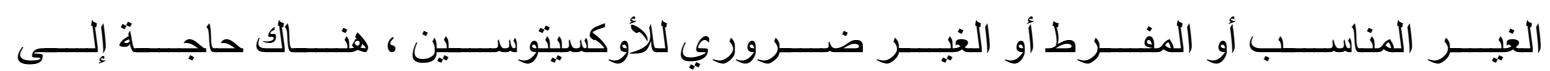
بروتوكول معياري ومحدد.

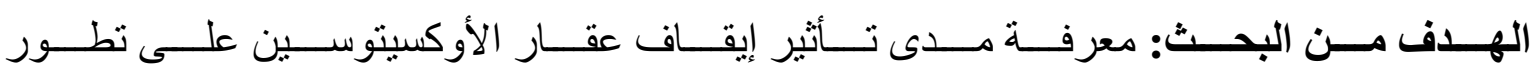

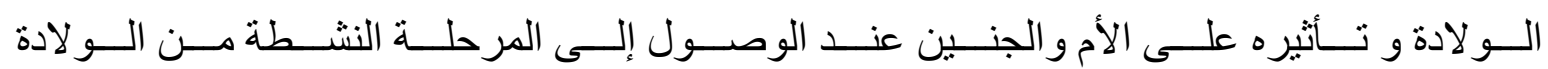
بالمقارنة باستمر ار عقار الأوكسيتوسين حتى نهاية الو لادة.

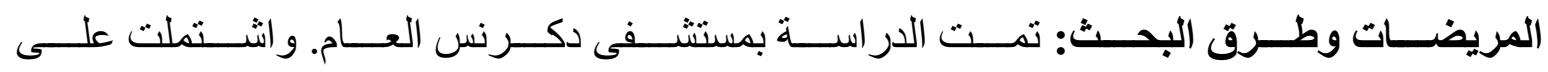

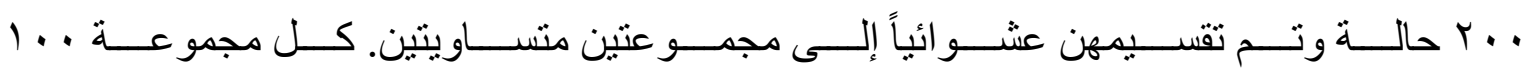

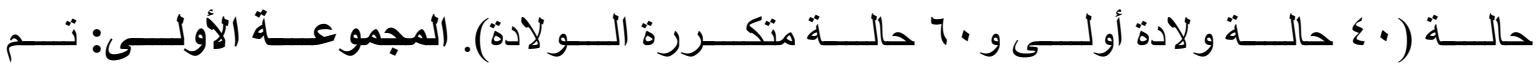




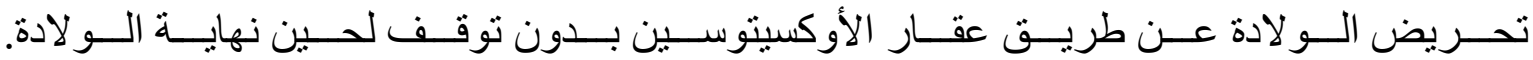

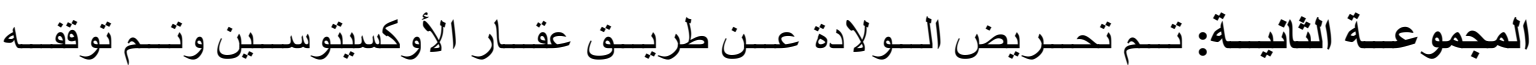

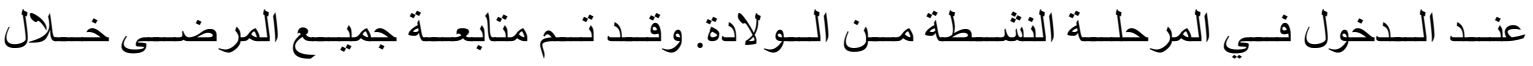

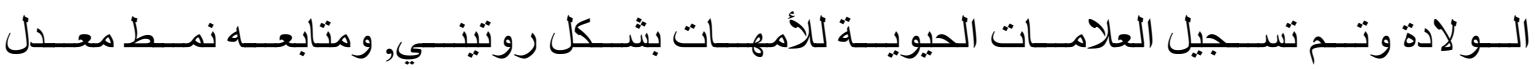

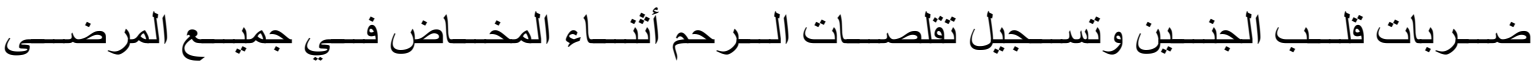

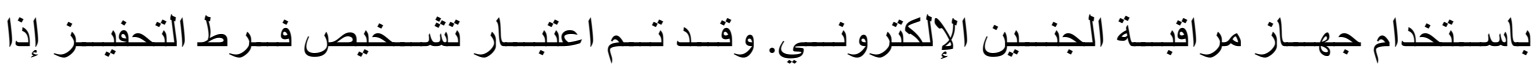

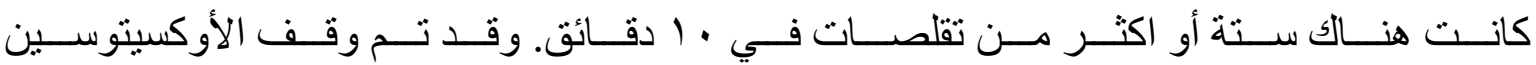

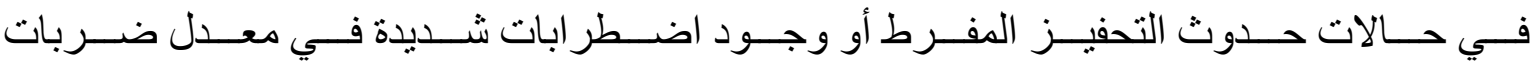
قلب الجنين وتم استبعاد هؤلاء المرضى من الدر اسة.

نتــائج البحــث: لــم يكـن هنــاك فــروق ذات دلالـــة إحصــائية بــين المجمــوعتين مــن حيـــث

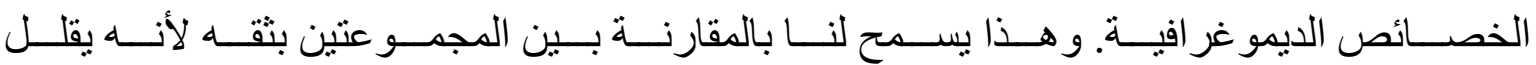

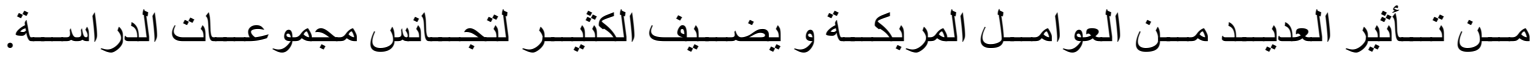

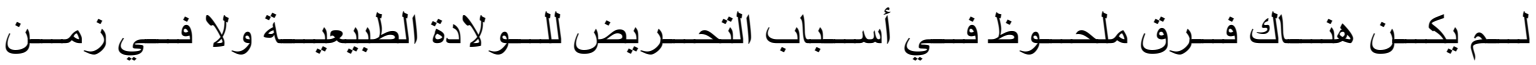

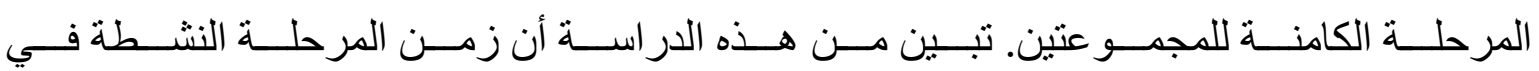

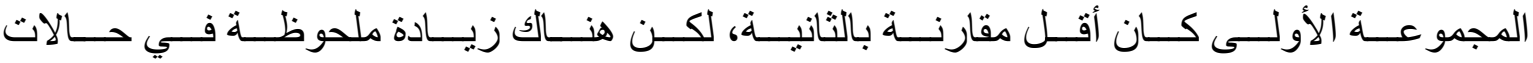

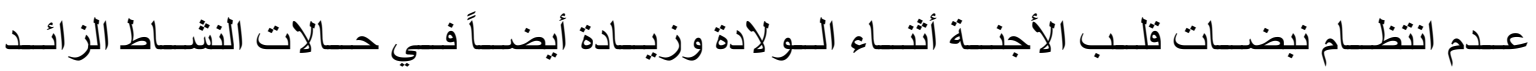

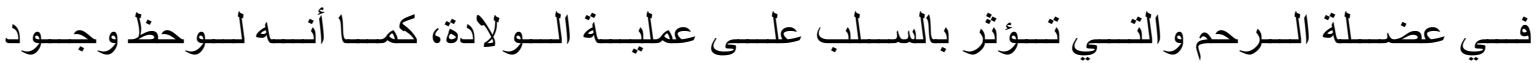

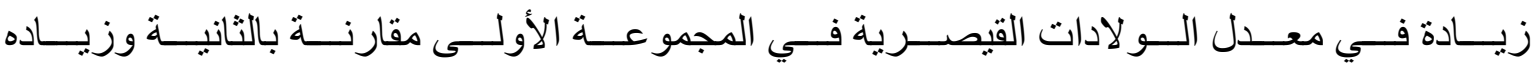

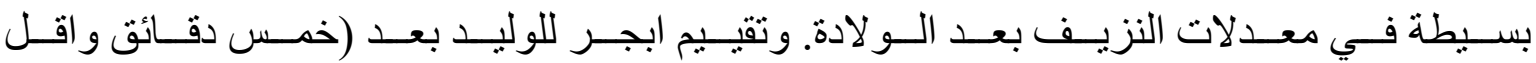

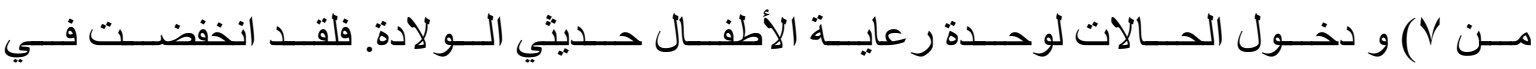
المجمو عة الثانية ومع ذلك فإن هذا الانخفاض لم يصل لالالة إحصائية.

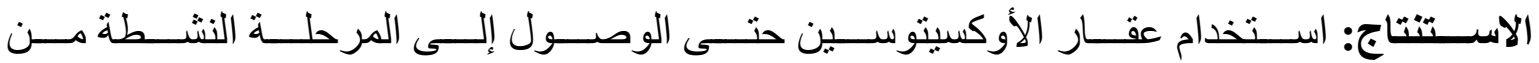

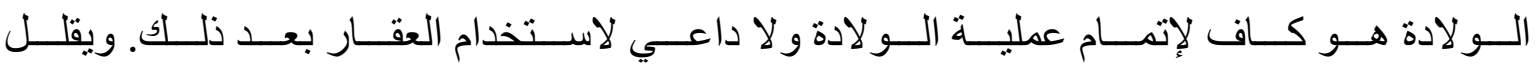

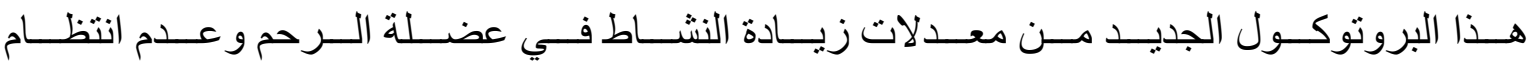

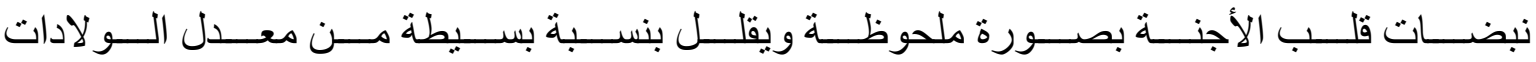

